\title{
Pathogenesis of alphavirus infection as demonstrated by infection of ECV 304 transformed human umbilical vein capillary endothelial cells with Semliki Forest virus
}

\author{
R. JAKOB
}

Institute for Applied Cell Culture, Balanstrasse 6, D-8000 Munich, Germany

\begin{abstract}
Summary. Routes of alphaviral entry have been studied with the transformed human endothelial vein cell line ECV 304. This cell line can be cultured on tissue culture inserts which permits apical (lumenal) and basolateral (ablumenal) cell surfaces to be infected and observed separately. Semliki Forest Virus (SFV), a prototype alphavirus, was able to infect and replicate from both the apical and basolateral sides. Transcytosis is not the route by which SFV passes the endothelial cell barrier as demonstrated by polarised infection of junctionally tight ECV monolayers in which translation was inhibited. A "grow-through" replication may play a role in SFV pathogenesis. Infected ECV cells produced interfering substances that inhibited viral infection. Higher multiplicities of infection resulted in infection and complete destruction of the monolayer.
\end{abstract}

\section{Introduction}

Semliki Forest virus (SFV) is a positive-stranded RNA virus that causes extensive cytopathic effects in a number of susceptible human and animal cell lines. ${ }^{1-3}$ It is one of the best studied viruses of the genus Alphavirus belonging to the family Togaviridae. ${ }^{4}$ Alphaviruses have a worldwide distribution and cause many clinical syndromes, encephalitis being the most dangerous complication. ${ }^{5}$

Although there is a wealth of information on the structure and assembly of alphaviruses, ${ }^{6}$ information on the pathogenesis of alphavirus infections is scarce. Mosquitoes transmit the virus through their bites. Infectious virions are present throughout the whole lifespan of the insects and survive in their salivary glands. ${ }^{7}$ However, at the molecular level some enigmas remain. It is unclear how the virus, once inside the host's body fluids, succeeds in passing from the blood to the tissue to cause its dramatic effects. Alphaviruses enter the cells by receptor-mediated endocytosis. ${ }^{8-11}$ Attachment to the plasma membrane occurs preferentially to microvilli and is followed by lateral movement of the virus to coated pits. ${ }^{12}$ The engulfed coated pit forms a coated vesicle, ${ }^{13}$ which itself is rapidly uncoated ${ }^{14}$ and taken up by an endosome. However, direct fusion with the plasma membrane has also been observed..$^{15}$ ATP-dependent proton pumps ${ }^{16}$ lower the $\mathrm{pH}$ to $<6.2$ which leads to the fusion of viral and endosomal membranes ${ }^{17-22}$ thus allowing the nucleocapsid to penetrate finally into the host cell's cytoplasm. The nucleocapsid is uncoated, which liberates

Received 26 March 1992; revised version accepted 29 Nov. 1992. the viral RNA. This will then be translated to produce progeny virus.

The first cells encountered by the virions are the blood mononuclear cells. ${ }^{23}$ All mobile blood mononuclear cells are known to be infectable with alphaviruses. ${ }^{24-30}$ Thus a possible entry route is the migration of leucocytes ${ }^{31-33}$ through the endothelial lining of blood vessels. Another entry mechanism might be infection of endothelial cells themselves.

Endothelial cells are highly polarised, their apical (lumenal) plasma membrane having a composition

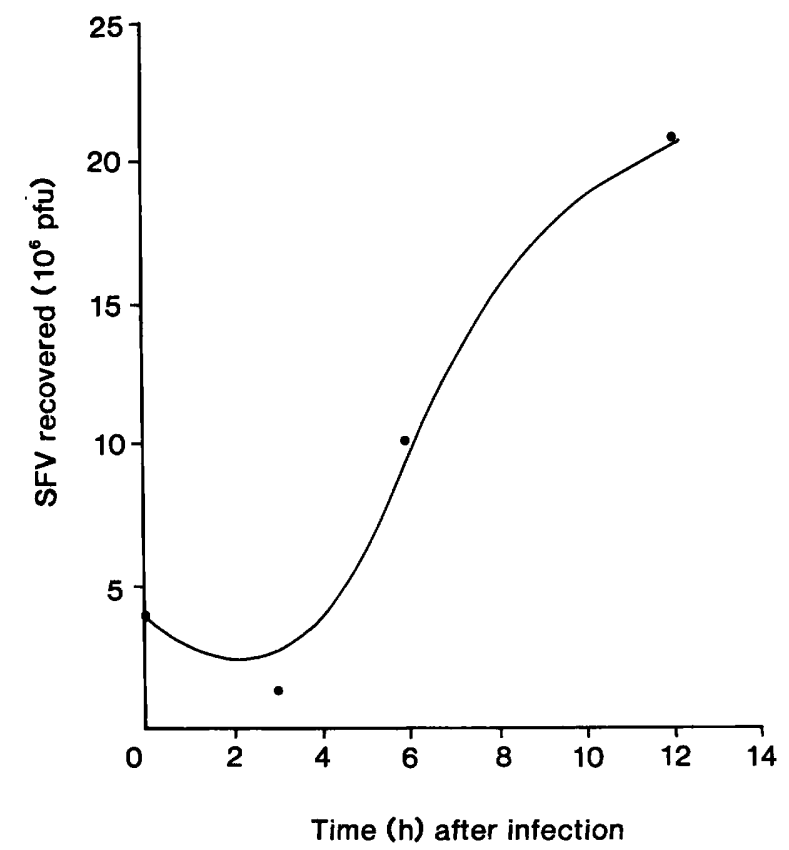

Fig. 1. Production of extracellular virus in the course of infection of a $25-\mathrm{cm}^{2}$ ECV 304 cell monolayer with SFV at 1 MOI. 
different from that of their basolateral (ablumenal) plasma membrane. They are able to form tight junctions with each other, thus restricting the passive diffusion of solvents. ${ }^{34}$ The ability of endothelial cells to form a confluent monolayer bound together by tight junctions is also the basis for the blood-brain barrier. ${ }^{35,36}$ Components passing this barrier are transported actively to reach the underlying intima. ${ }^{37}$ This is especially true for viruses. Infecting viruses could either be transcytosed or its progeny could bud from the basolateral membrane. Once the endothelial cell barrier is breached, a large number of susceptible cells can be infected. ${ }^{38,39}$ In particular, neuronal cells can be destroyed by SFV. ${ }^{40-41}$

ECV 304 is a transformed human umbilical vein capillary endothelial cell line. ${ }^{42}$ It was chosen to study SFV pathogenesis because it may represent a useful model to elucidate vertical transmission of alphaviruses from the mother to the embryo.

\section{Material and methods}

\section{Chemicals, buffers, media and cells}

All chemicals were of analytical quality. Horseradish peroxidase type II was from Sigma and kept frozen as a $0.1 \mu \mathrm{g} / \mathrm{ml}$ PBS A (137 mM NaCl, $2.7 \mathrm{~mm}$ $\mathrm{KCl}, 8 \mathrm{mM} \mathrm{Na}_{2} \mathrm{HPO}_{4} \times 12 \mathrm{H}_{2} \mathrm{O}, 1.5 \mathrm{mM} \mathrm{KH}_{2} \mathrm{PO}_{4}$ ) stock solution at $-20^{\circ} \mathrm{C}$. ECV 304 (a generous gift from Dr Takahashi, National Defense Medical College, 3-2, Namiki, Tokorozawa, Saitama, Japan) and human umbilical vein capillary endothelial cells (HUVEC, isolated according to Thilo-Körner ${ }^{37,43}$ with collagenase $0 \cdot 1 \%$, Sigma, type VII in PBS A) were grown in Medium 199 containing glutamine and antibiotics (Gibco Paisley), supplemented with heat inactivated fetal calf serum (FCS) $10 \%$. Plaque assay was performed in Vero cells grown on six-well clusters (Costar, Cambridge, USA) in DMEM (Biochrom, Berlin, Germany) supplemented with FCS $10 \%$, penicillin $100 \mathrm{IU} / \mathrm{ml}$, streptomycin $100 \mu \mathrm{g} / \mathrm{ml}$ and $2 \mathrm{mM}$ glutamine. Complete medium 199 with cycloheximide $200 \mu \mathrm{g} / \mathrm{ml}$ was prepared freshly before each experiment.

\section{Virus and infection}

SFV was grown in C6/36 Aedes albopictus (insect larvae) cells and isolated according to Kääriäinen and Gomatos. ${ }^{44}$ Samples were stored at $-80^{\circ} \mathrm{C}$ in sucrose $60 \% \mathrm{w} / \mathrm{v}$. Plaque forming units ( $\mathrm{pfu}$ ) were determined by plaque assay. For each series of infections a fresh sample of virus was used. The virus titre was $6.3 \times 10^{8} \mathrm{pfu} / \mathrm{ml}$. Cells grown on Costar Transwell ${ }^{\circledR}$ tissue culture plate inserts (pre-treated for $2 \mathrm{~h}$ with fibronectin $0.04 \%$ in PBS A) of $6.5 \mathrm{~mm}$ diameter and $3 \mu \mathrm{m}$ pore size were infected either from the lumenal (apical) or ablumenal (basolateral) side with stock virus diluted in Medium 199. In the course of infection, $50-\mu 1$ volumes were collected either from apical or basolateral supernates at times $<24 \mathrm{~h}$ post-infection (hpi) to avoid collecting during cytopathic effect (CPE) and replaced with fresh complete medium. The samples were analysed by plaque assay.

\section{Enzymatic assay of cell monolayer tightness}

A modification of the o-dianisidine enzymatic assay $^{45}$ was used. A substrate mixture composed of $6 \mathrm{ml}$ of $40 \mathrm{mM} \mathrm{NaH} \mathrm{PO}_{4}, 2 \mu \mathrm{l} \mathrm{H}_{2} \mathrm{O}_{2} 30 \%$ and $50 \mu \mathrm{l}$ odianisidine $1 \%$ in methanol was prepared. To each $900 \mu \mathrm{l}$ of this substrate mixture, $100 \mu \mathrm{l}$ of a solution to be assayed was added in a $1 \mathrm{~cm}$ quartz cuvette and the increase in absorption at $560 \mathrm{~nm}$ was determined as a linear function of time. Horseradish peroxidase (HRP) (100 $\mu$ l of a $0 \cdot 1 \mu \mathrm{g} / \mathrm{ml}$ solution) was used as reference and set to $100 \%$ activity. In principle, ECV 304 monolayers were considered to be tight if less than $2.5 \%$ of the administered horseradish reference solution passed the cell monolayer either from the lumenal or ablumenal side within $2 \mathrm{~h}$ of diffusion time. This value corresponds to the naturally exocytosed HRP after uptake. ${ }^{45}$ Tightness was assayed at the beginning and at the end of each experiment.

\section{Determination of intracellular virus}

Intracellular virus was determined by plaque assay after lysis of cells by repeated freezing and thawing. Briefly, cells were washed five times with PBS A, subjected to three freezing and thawing cycles, scraped off their support with a rubber rod (Costar) and homogenised with 10 gentle strokes in a tight fitting Dounce homogeniser with PBS A.

\section{Infective centre assay}

Infective centres were counted as described by Davey and Dalgarno. ${ }^{46}$

\section{Results}

\section{Susceptibility of ECV 304 to SFV infection}

ECV 304 (passage 70-90) cells were grown to confluency in $75-$ or $25-\mathrm{cm}^{2}$ bottles and infected with SFV. At various times (h) post-infection (hpi) the virus titre in the supernate was determined by plaque assay (fig. 1). ECV 304 shows a typical viral replication curve. However, while infecting cells with low multiplicities of virus/cell (MOI) no cytopathic effect (CPE) could be observed even up to 6 days post-infection (table I). The cells were still confluent and lowering the $\mathrm{pH}$ of the medium to $\mathrm{pH} 5.8$ for $30 \mathrm{~min}$ did not induce the formation of syncytia, as has been observed in SFV-infected Aedes albopictus cells. This contrasts to the observed cytopathic effect induced by low multiplicities of SFV on HUVEC (fig. 2a). Only higher multiplicities of SFV induced CPE on ECV 304 cells (fig. 2b). After repeated washing and freezing and 
Table I. Multiplicities of infection (MOI) by SFV and CPE on ECV 304 cells

\begin{tabular}{rrr} 
& \multicolumn{2}{c}{ CPE at } \\
\cline { 2 - 3 } MOI & & \\
& 48 hpi & $144 \mathrm{hpi}$ \\
\hline $0 \cdot 5$ & - & - \\
$1 \cdot 5$ & - & - \\
6 & - & - \\
17 & + & + \\
250 & + & +
\end{tabular}

ECV cells were grown to confluency in $25-\mathrm{cm}^{2}$ bottles, infectedafter medium change; a second medium change was performed at $72 \mathrm{hpi}$.

thawing of infected cells, intracellular virus could be detected (data not shown). There was a good correlation between MOI and infective centres at higher MOI (table II). These results suggest a possible persistent infection of ECV with SFV at low MOI challenge.

\section{Production of interferon-like mediators}

To clarify whether the production of interfering substances could account for the observed dose dependency of CPE, culture media from infected ECV monolayers ( $100 \mathrm{MOI}, 25 \mathrm{~cm}^{2}$ ) were collected at 15, 40 and $130 \mathrm{hpi}$. The viral particles were pelleted by
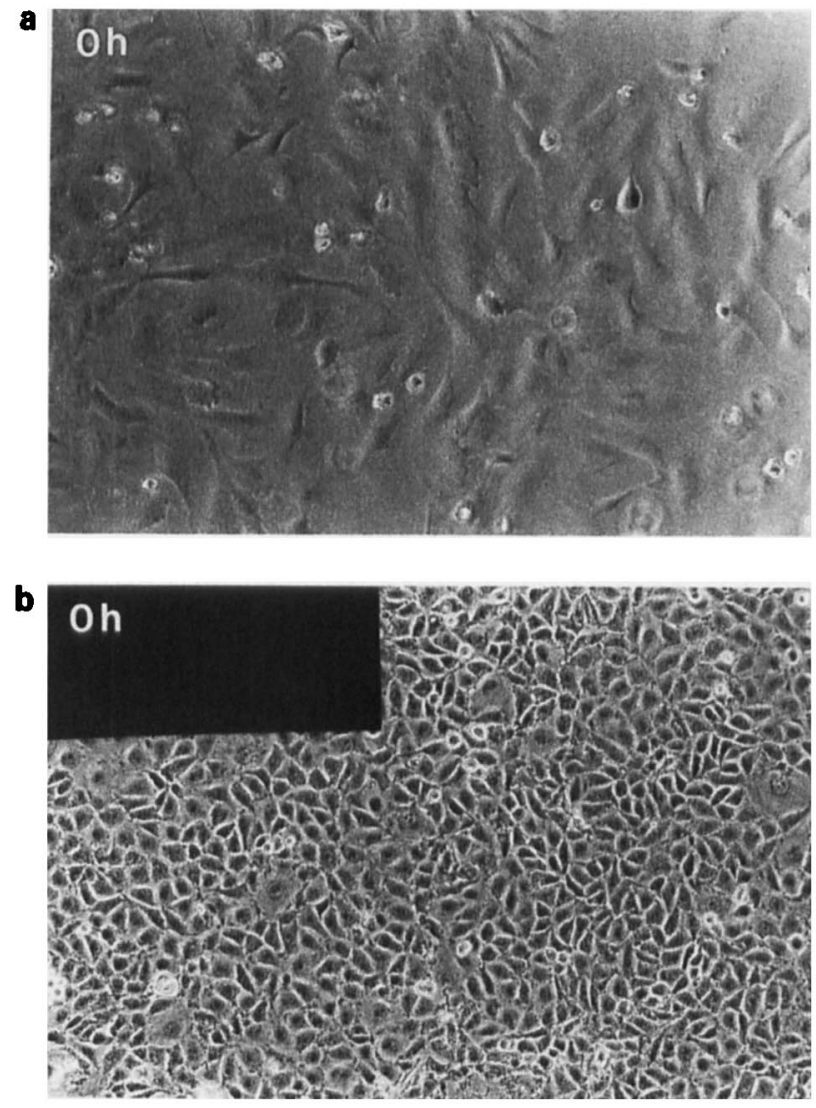

Table II. Correlation between MOI and infective centres in SFV-infected ECV 304 cells

\begin{tabular}{|c|c|}
\hline MOI & $\begin{array}{c}\text { Infective } \\
\text { centres } \\
(\%)\end{array}$ \\
\hline 10 & 3 \\
\hline 35 & 14 \\
\hline 100 & 30 \\
\hline 400 & 106 \\
\hline
\end{tabular}

centrifugation for $1.5 \mathrm{~h}$ at $150000 \mathrm{~g}$. The upper half of the resultant supernate was used as medium for reinfection of fresh ECV monolayers (100 MOI, $25 \mathrm{~cm}^{2}$ ). One culture bottle was infected during addition of fresh medium and samples of all of the extracellular media were collected in the course of infection. The older the medium was, the lower became the extracellular virus titre (fig. $3 \mathrm{a}$ ). To rule out a possible influence of depletion of essential nutrients in the medium, it was collected from uninfected cells cultured for $0,15,40$ and $130 \mathrm{~h}$. The recycled media were then used during infection of fresh confluent ECV cultures. No difference in extracellular virus production was observed (fig. $3 \mathrm{~b}$ ), hence the age of the uninfected ECV medium had no measurable effect on viral replication. Thus SFV-infected ECV cells are capable of producing interfering substances, which inhibit subsequent SFV production.
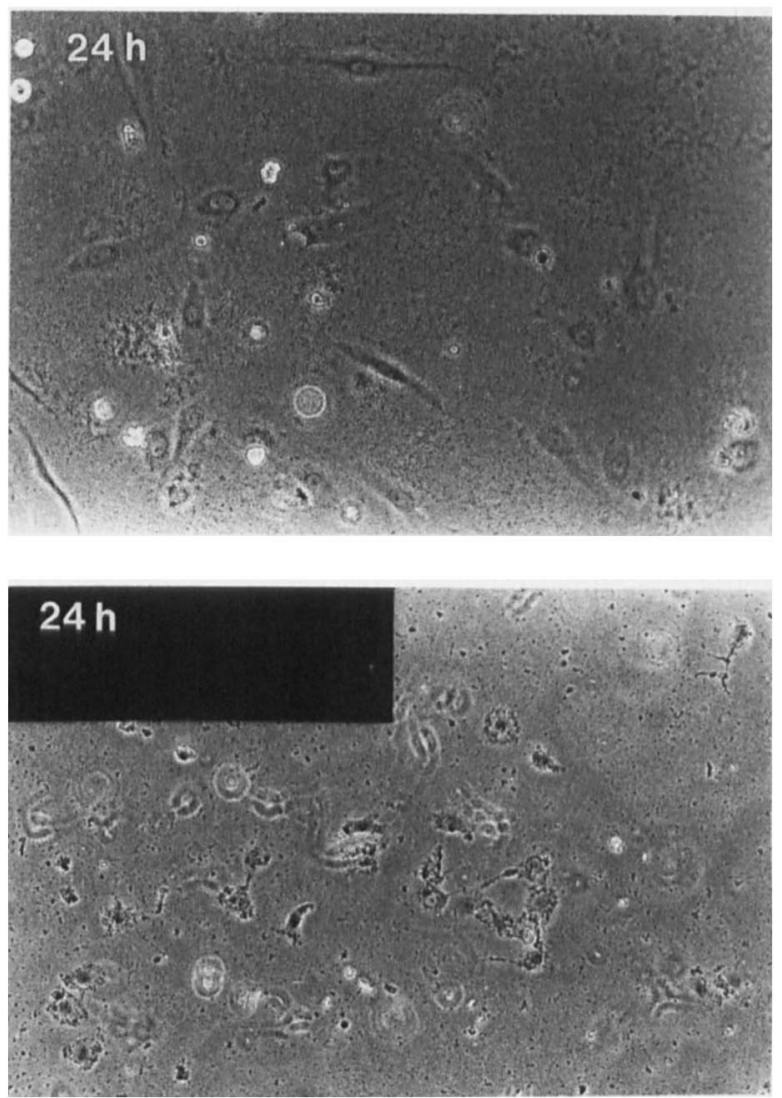

Fig. 2. a, Cytopathic effect of SFV (0.5 MOI) in HUVEC 24 hpi. b, Cytopathic effect of SFV (50 MOI) on ECV 304 at 24 hpi. 


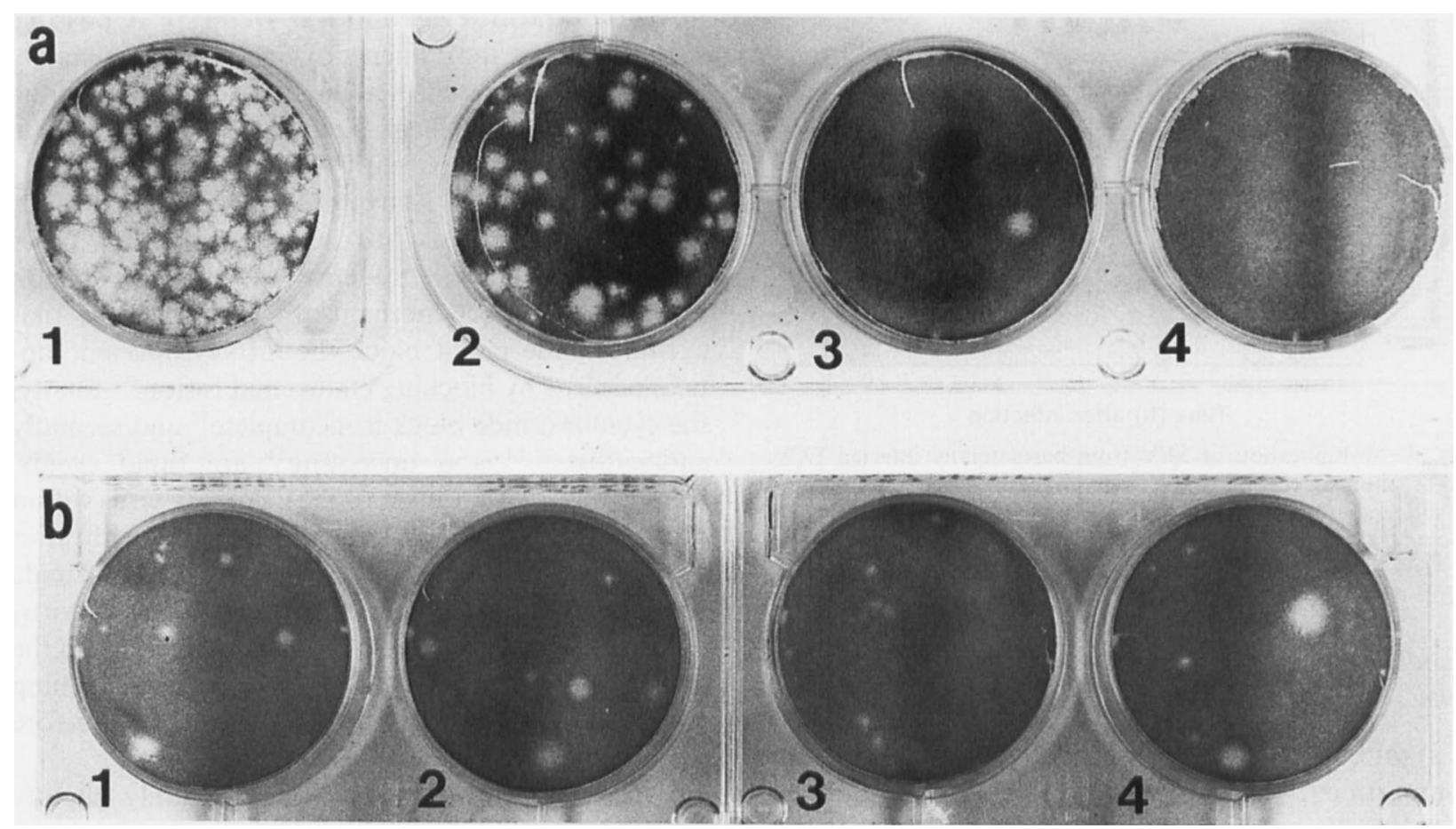

Fig. 3. a, Effect of clarified infected ECV culture medium on extracellular virus production $45 \mathrm{hpi}: 1$, fresh medium; 2, $15 \mathrm{hpi} ; 3,40 \mathrm{hpi}$; 4, $130 \mathrm{hpi}$. Dilution for plaque assay: $10^{-1}$. b, Effect of uninfected ECV culture medium on extracellular virus production 48 hpi: 1, fresh medium; 2, $15 \mathrm{hpi} ; 3,40 \mathrm{hpi} ; 4,130 \mathrm{hpi}$. Dilution for plaque assay, $10^{-2}$.

\section{Transcytosis assays}

Vero cells grown to confluency on Transwell ${ }^{\circledR}$ membranes were used for comparative studies. Their tightness had been tested as described and results are reported only if monolayers were confluent at the beginning and at the end of each experiment. The Vero cells could be infected from both the basolateral and apical sides. In the course of infection, budding virus was detected in both the apical and basolateral supernates regardless of the side of infection (data not shown). To examine whether incoming (parental) virus could be transcytosed through the Vero cell monolayer, $50 \mu \mathrm{l}$ of the SFV stock solution suspended in $500 \mu \mathrm{l}$ of complete medium 199 containing cycloheximide $500 \mu \mathrm{g} / \mathrm{ml}$ (to inhibit translation) was added to the apical or basolateral side in parallel assay of tight Vero cell monolayers. Addition of cycloheximide had no effect on cell monolayer tightness during the course of the experiment. Every $5 \mathrm{~h}$ the cycloheximidecontaining medium was reconstituted. Over a 15-h period transcytosed virus could not be detected by plaque assay.

The same experimental design was applied to tight ECV monolayers. They were achieved by plating out one $75-\mathrm{cm}^{2}$ bottle of confluent ECV 304/two inserts. After $24 \mathrm{~h}$, the basolateral medium was replaced. Tightness was detected irregularly at $2-4$ days after seeding. This might be due to the existence of tiny areas uncovered by cells at seeding which take more time to overgrow completely.

Fresh SFV stock solution $(10 \mu$ l) in medium 199 containing cycloheximide $500 \mu \mathrm{g} / \mathrm{ml}$ was added to

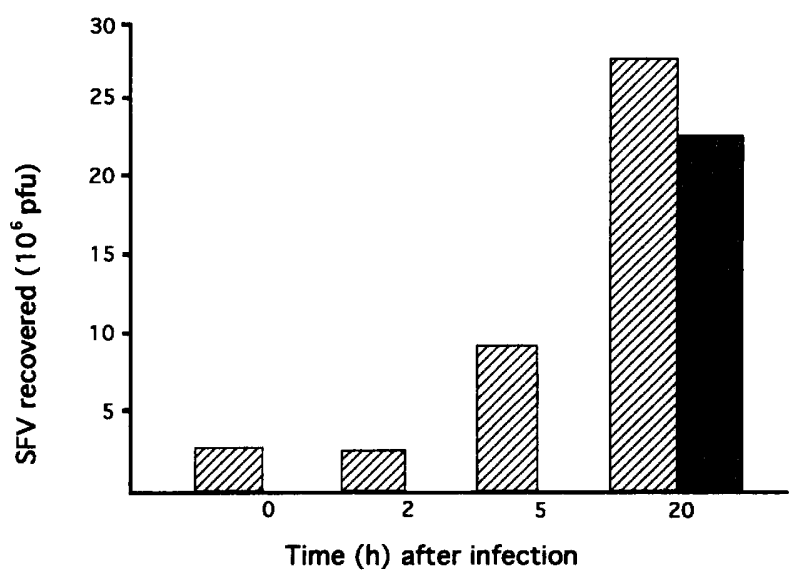

Fig. 4. Multiplication of SFV from apically infected ECV. Tight monolayers of ECV were infected apically, and apical ( $\square)$ and basolateral ( supernates were assayed for SFV.

the basolateral or apical side of the cells respectively and the course of infection was followed by plaque assay. Every $5 \mathrm{~h}$ the cycloheximide-containing medium was replenished on each side. No transcytosed virus was detected over the 15 -h observation period.

\section{Budding of SFV from the apical side of ECV cells}

Tight ECV monolayers were infected from the upper side as described above and samples were collected from the apical and basolateral sides over a 24-h period. Extracellular virus titre rose on the apical side (fig. 4), whereas virus particles could be detected by plaque assay basolaterally only late in infection $(\mathrm{n}=2)$. 


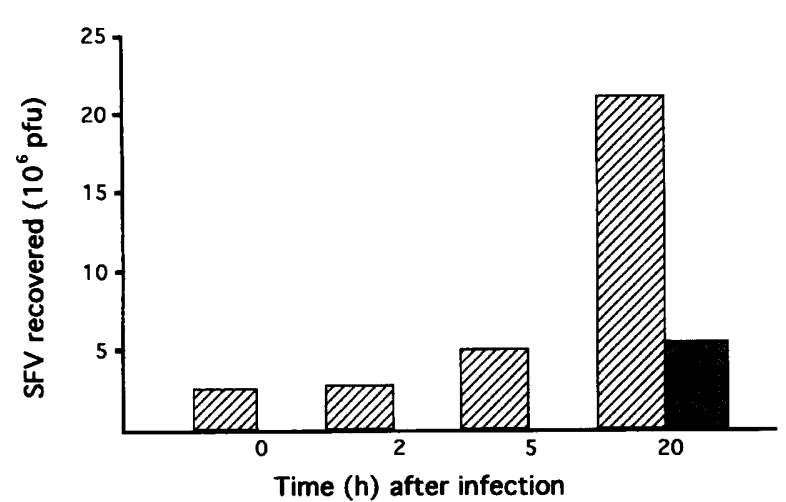

Fig. 5. Multiplication of SFV from basolaterally infected ECV Tight monolayers of ECV were infected basolaterally, and basolateral $(\square)$ and apical $(\mathbb{N})$ supernates were assayed for SFV. No viral replication was detected at the apical side.

\section{Budding of SFV from the basolateral side of ECV cells}

Tight ECV monolayers were infected from the lower compartment (basolateral side) as described above and samples were collected from the apical and basolateral side during the course of infection. Extracellular virus titres rose on the basolateral side (fig. 5, $\mathrm{n}=2$ ), whereas infectious virions could be detected apically only late in the infection.

\section{Discussion}

The present study shows that ECV 304 transformed human umbilical vein capillary endothelial cells provide a useful model to study alphaviral pathogenesis. Like HUVEC, ${ }^{47}$ ECV cells can be infected and produce interfering substances. ECV cells are especially capable of coping with viral challenge at low MOI, when the production of interferon substantially hinders cytopathic effects. The tightness of intercellular junctions cannot reliably be assessed microscopically. Some apparently densely tight ECV monolayers permitted the passage of up to $11 \%$ of the reference enzyme solution. Recently, Dropulic and Masters determined the confluency of their cell monolayers by colouring them with haematoxylin and eosin and checking by eye. ${ }^{48}$ They found preferential apical budding at a ratio of about 10:1 for SFV strains infecting mouse brain endothelial cells from the apical side. ${ }^{48}$ The basolateral budding detected in the mouse brain endothelial cell system could be caused by some leakiness of their monolayers, as tightness was not tested. The present results suggest that tight monolayers of endothelial cells might slow down a "grow-through" mechanism of infection, either from the apical or from the basolateral side, since "grow-through virus" is detected only at $20 \mathrm{hpi}$, whereas at $5 \mathrm{hpi}$ viral titre was already detectable at the side of primary infection. SFV can also infect from the basolateral side, making re-infection of primarily apically infected cell layers possible. The apical infectious virus titre after basolateral infection did not rise as high as the basolateral infectious virus titre after apical infection (figs. 4 and 5). A possible reason might be the influence of gravity. Unfortunately there is no commercial system available to reverse the orientation of the cells so as to obviate this problem.

Transcytosis is apparently not the method used by infectious SFV to pass through tight ECV monolayers, although transcytosis has been reported for other virus-endothelial cell systems ${ }^{49}$ and is a common vesicular transport mechanism. ${ }^{50}$ It is possible that cycloheximide might block the intracytoplasmic uptake of virus by blocking endosomal fusion. ${ }^{51}$ Firstly, the cycloheximide block is incomplete ${ }^{52}$ and secondly endocytosis $^{53,54}$ and uncoating ${ }^{54}$ are rapid events, being completed for most of the incoming virus within c. $1 \mathrm{~h}$. Cycloheximide is known to be active only after a 1-h pre-incubation. ${ }^{55}$ Therefore, cycloheximide should be inhibiting the production of progeny virus only in the transcytosis assay. The salient finding of the infection studies with cycloheximide is that incoming virus seems to be degraded within the cell before transcytosis has a chance to occur.

Extracellular virus titres increased only slightly during the course of infection of ECV with SFV, but it should be borne in mind that this is partly provoked by serum de-activation of the virus-containing media. This becomes especially obvious in fig. 3. In summary, it seems that infection of ECV is only one of several pathways for invasion of SFV into underlying tissues. Infection of ECV with high multiplicities of SFV leads to cytopathic effects, i.e., destruction of cells and hence breakdown of the barrier formed through tight junctions. This leads to random invasion by parental and progeny virus and also to ingress of lymphocytes and other infectable blood cells. ${ }^{24-30}$ Production of interferons might protect endothelial cells to some extent against attack by SFV and it seems to be produced abundantly by ECV. On the other hand it might also facilitate cytotoxic effects of leucocytes ${ }^{56}$ and might even promote migration of infected leucocytes $^{31}$ via stimulation by interleukin $1 .{ }^{57}$ Recombinant $\gamma$-interferon has been shown to stimulate lymphocyte adhesion via ICAM-1 upregulation ${ }^{58}$ and human $\gamma$ interferon to increase T-lymphocyte adherence to HUVEC. ${ }^{59}$ This could then lead to increased penetration of infected lymphocytes. Furthermore, interferon has been reported to cause endothelial cell damage $^{60}$ and other cytokines to be directly involved in the break-down of the blood-brain barrier. ${ }^{61}$ Hence the action of interferon can be both beneficial and harmful. Like the trophoblast layer of the human placenta, which acts as an additional barrier to the transmission of infection from mother to fetus and which is also able to produce interferons, ${ }^{62}$ production of interferon by human umbilical vein endothelial cells might be a regulated protection mechanism against alphaviral infection.

The pathogenesis of alphaviral infection is only poorly understood. This is one of the reasons for the current lack of efficient therapeutic remedies. Acute encephalitis is the most dangerous complication 
caused by alphaviral infections and often has a fatal outcome. Alphavirus-caused diseases not only affect man but also domestic animals. Western equine encephalitis (WEE) and Venezuelan equine encephalitis (VEE) attack both man and animals and can lead to severe complications, especially in pregnancy. ${ }^{63-68}$ Discovering how the viruses get to their targets could lead to new insights into pathogenesis and facilitate the search for methods of prevention and cure.

\section{References}

1. Ulug ET, Garry RF, Bose HR. Cell killing by enveloped RNA viruses. In: Carrasco L (ed) Mechanisms of viral toxicity in animal cells. Boca Raton, FL, CRC Press. 1987: 91-113.

2. Stollar V. Arbovirus-vector cell interactions and host-range viral mutants. In: Yunger C (ed) Arboviruses in arthropod cells in vitro, vol 2. Boca Raton, FL, CRC Press. 1987: 91-110.

3. Stollar V. Togaviruses in cultured arthropod cells. In: Schlesinger RW (ed) The togaviruses. NY, Academic Press. 1980: 583-621.

4. Westaway EG, Brinton MA, Gaidamovich SY et al. Togaviridae. Intervirology 1985; 24 : 125-139.

5. Grimstad PR. Mosquitos and the incidence of encephalitis. In: Lauffer MA, Maramorosch $\mathrm{K}$ (eds) Advances in virus research. NY, Academic Press. 1983: 357-438.

6. Garoff H, Kondor-Koch C, Riedel H. Structure and assembly of alphaviruses. In: Cooper M, Henle W, Hofschneider PH et al. (eds) Current topics in microbiology and immunology. Berlin, Springer. 1982: 1-50.

7. Chamberlain RW. Epidemiology of arthropod-borne togaviruses: The role of arthropods as hosts and vectors and of vertebrate hosts in natural transmission cycles: In: Schlesinger RW (ed) The togaviruses. NY, Academic Press. 1980: 175-227.

8. White J, Kielian M, Helenius A. Membrane fusion proteins of enveloped animal viruses. $Q$ Rev Biophys 1983; 16: 151-195.

9. Marsh M. The entry of enveloped viruses into cells by endocytosis. Biochem $J$ 1984; 218: 1-10.

10. Asano A, Asano K. Molecular mechanism of virus entry to target cells. Tumor Res 1984; 19 : 1-20.

11. Kielian $\mathbf{M}$. The membrane fusion protein and endocytic entry pathway of Semliki Forest virus. In: Molecular mechanisms in the regulation of cell behavior. NY, A. R. Liss. 1987: 197-202.

12. Marsh M, Helenius A. Virus entry into animal cells. Adv Virus Res $1989 ; 36$ : 107-151.

13. Linden CD, Roth TF. The structure of coated vesicles. In: Cuatrecasas P, Roth TF (eds) Receptor-mediated endocytosis, vol 15(B). London, Chapman and Hall. 1983: $21-44$.

14. Anderson RG, Brown MS, Goldstein JL. Role of the coated endocytic vesicle in the uptake of receptor-bound low density lipoprotein in human fibroblasts. Cell 1977; 10: 351-364.

15. Fan DP, Sefton BM. The entry into host cells of Sindbis virus, vesicular stomatitis virus and Sendai virus. Cell 1978; 15: 985-992.

16. Yamashiro DJ, Maxfield FR. Regulation of endocytic processes by pH. Trends Biochem Sci 1988; 9: 190-193.

17. Kielian MC, Marsh M, Helenius A. Entry of alphaviruses. In: Schlesinger SS, Schlesinger MJ (eds) The togaviridae and flaviviridae. NY, Plenum. 1986: 91-119.

18. Marsh M, Bolzau E, White J, Helenius A. Penetration of Semliki Forest virus from acidic prelysosomal vacuoles. Cell 1983; 32: 931-940.

19. Richman D, Hostettler KY, Yazaki PJ, Clark S. Fate of influenza A viron proteins after entry into subcellular fractions of LLC cells and the effect of amantadine. Virology 1986 ; 151 : 200-210.

20. Talbot PJ, Vance DE. Biochemical studies on the entry of
Sindbis virus into BHK-21 cells and the effect of $\mathrm{NH}_{4} \mathrm{Cl}$. Virology 1982; 118: 451-455.

21. Yoshimura A, Onishi S-I. Uncoating of influenza virus in endosomes. J Virol 1984; 51 : 497-504.

22. Helenius A. Semliki Forest virus penetration from endosomes: A morphological study. Biol Cell 1984; 51: 181-186.

23. Pathak S, Webb HE. Possible mechanisms of transport of Semliki Forest virus into and within mouse brain. An electron-microscopic study. J Neurol Sci 1974; 23: 175-184.

24. Wu LX, Ilonen J, Makela MJ, Salonen R, Marusyk R, Salmi AA. Impaired interleukin 1 and interleukin 2 production following in vitro abortive infection of murine spleen mononuclear cells by Semliki Forest virus. Cell Immunol 1988; 116: 112-122.

25. Landolfo S, Gariglio M, Gribaudo G, Jemma C, Giovarelli M, Cavallo G. Interferon-gamma is not an antiviral, but a growth-promoting factor for $\mathrm{T}$ lymphocytes. Eur $J$ Immunol 1988; 18: 503-509.

26. Liprandi F, Gomez B, Walder R. Replication of alphaviruses in cultures of donkey monocytes. Arch Virol 1986; 87: 163-171.

27. Schlesinger JJ, Brandriss MW. Antibody-mediated infection of macrophages and macrophage-like cell lines with 17Dyellow fever virus. J Med Virol 1981; 8: 103-117.

28. Cook RF, Avery RJ, Dimmock NJ. Infection of chicken erythrocytes with influenza and other viruses. Infect Immun $1979 ; 25: 396-402$.

29. Levitt NH, Miller HV, Edelman R. Interaction of alphaviruses with human peripheral leukocytes: in vitro replication of Venezuelan equine encephalomyelitis virus in monocyte cultures. Infect Immun 1979; 24: 642-646.

30. Seay AR, Wolinsky JS. Ross River virus-induced demyelination: II. Ultrastructural studies. Ann Neurol 1983; 14: $559-568$

31. Moser R, Schleiffenbaum B, Groscurth P, Fehr J. Interleukin 1 and tumor necrosis factor stimulate human vascular endothelial cells to promote transendothelial neutrophil passage. J Clin Invest 1989; $83: 444455$.

32. Marchesi V, Florey $\mathrm{H}$. Electron micrographic observations on the emigration of leukocytes. $J$ Exp Physiol 1960; 45: 343-348.

33. Shaw JO. Leukocytes in chemotactic fragment-induced lung inflammation. Vascular emigration and alveolar surface migration. Am J Pathol 1980; 101 : 283-302.

34. Zetter BR, Johnson LK, Shuman MA, Gospodarowicz D. The isolation of vascular endothelial cell lines with altered cell surface and platelet-binding properties. Cell 1978; 154: 501-509.

35. Bradbury M. (ed). The concept of a blood brain barrier. NY, John Wiley and Sons. 1979.

36. Rapoport SI. (ed). Blood brain barrier in physiology and medicine. NY, Raven Press. 1976.

37. Thilo-Körner GS. Die Endothelzelle - in in vitro-Modell der Gefässwandforschung. Bioengineering $1989 ; 6$ : 32-42.

38. Shahar A, Lustig S, Akov Y, David Y, Schneider P, Levin R. Different pathogenicity of encephalitic togaviruses in organotypic cultures of spinal cord slices. J Neurosci Res $1990 ; 25: 345-352$.

39. Pathak S, Webb HE. Semliki Forest virus multiplication in mouse brain with reference to demyelination. $J$ Physiol 1983; 339: 17P.

40. Pathak S, Webb HE, Oaten SW, Bateman S. An electron microscopic study of the development of virulent and avirulent strains of Semliki Forest virus in mouse brain. $J$ Neurol Sci 1976; 28: 289-295.

41. Zlotnik I, Harris WJ. The changes in cell organelles of neurons in the brains of adult mice and hamsters during Semliki Forest virus and louping ill encephalitis. Br J Exp Pathol $1970 ; 51: 37-42$.

42. Takahashi K, Sawasaki Y, Hata J-I, Mukai K, Goto T. Spontaneous transformation and immortalization of human endothelial cells. In Vitro Cell Develop Biol 1990; 25 : 265-274.

43. Thilo-Körner DGS, Heinrich D, Temme H. Endothelial cells in culture. In: Thilo-Körner DGS, Freshney RI (eds) The endothelial cell-a pluripotent control cell of the vessel wall. Basel, S. Karger. 1983: 158-202.

44. Kääriäinen L, Gomatos PJ. A kinetic analysis of the synthesis in 
BHK 21 cells of the RNAs specific for Semliki Forest virus. $J$ Gen Virol 1969; 5: 251-265.

45. Steinman RM, Cohn ZA. The interaction of soluble horseradish peroxidase with mouse peritoneal macrophages in vitro. $J$ Cell Biol 1972; 55: 186-204.

46. Davey MW, Dalgarno L. Semliki Forest virus replication in cultured Aedes albopictus cells: studies on the establishment of persistence. J Gen Virol 1974; 24: 453-463.

47. Eichhorn S, Eldor A, Vlodavsky I, Fuks Z, Panet A. Production and characterization of interferon from endothelial cells. $J$ Cell Physiol 1985; 122 : 200-204.

48. Dropulic B, Masters CL. Entry of neurotropic arboviruses into the central nervous system: an in vitro study using mouse brain endothelium. J Infec Dis 1990; 161: 685-691.

49. Bass DM, Trier JS, Dambrauskas R, Wolf JL. Reovirus type 1 infection of small intestinal epithelium in suckling mice and its effect on M cells. Lab Invest 1988; 55: 226-235.

50. Hubbard AL. Vesicle traffic and plasma biogenesis in polarized hepatocytes. 22nd annual meeting of the Swiss societies for Experimental Biology, Zürich. Experientia 1990, S12-2.

51. Seglen PO. Inhibitors of lysosomal functions. Methods Enzymol 1983; 96: 737-764.

52. Amenta JS, Sargus MJ, Baccino FM. Inhibition of basal protein degradation in rat embryo fibroblasts by cycloheximide: Correlation with activities of lysosomal proteases. $J$ Cell Physiol 1978; 97: 267-284.

53. Gruenberg JE, Howell KE. Reconstitution of vesicle fusions occurring in endocytosis with a cell-free system. EMBO J 1986; 5: 3091-3101.

54. Marsh M, Bolzau E, Helenius A. Penetration of Semliki Forest virus from acidic prelysosomal vacuoles. Cell 1983; 32 : 931-940.

55. Kovacs AL, Seglen PO. Inhibition of hepatocytic protein degradation by methylaminopurines and inhibitors of protein synthesis. Biochim Biophys Acta 1981; 676: 213-220.

56. Peri G, Chiaffarino F, Bernasconi S, Padura IM, Mantovani A.
Cytotoxicity of activated monocytes on endothelial cells. $J$ Immunol 1991; 144: 1444-1448.

57. Miossec $\mathrm{P}$, Ziff M. Immune interferon enhances the production of interleukin 1 by human endothelial cells stimulated with lipopolysaccharide. J Immunol 1986; 137: 2848-2852.

58. Dustin ML, Springer TA. Lymphocyte function-associated antigen-1 (LFA-1) interaction with intercellular adhesion molecule-1 (ICAM-1) is one of at least three mechanisms of lymphocyte adhesion to cultured endothelial cells. $J$ Cell Biol 1988; 107: 321-331.

59. Yu CL, Haskard DO, Cavender D, Johnson AR, Ziff M. Human gamma interferon increases the binding of $T$ lymphocytes to endothelial cells. Clin Exp Immunol 1985; 62: $554-560$.

60. Dvorak HF, Gresser I. Microvascular injury in pathogenesis of interferon-induced necrosis of subcutaneous tumors in mice. J Natl Cancer Inst 1989; 81: 497-502.

61. Chaturvedi UC, Dhawan R, Khanna, Mathur A. Breakdown of the blood-brain barrier during dengue virus infection of mice. J Gen Virol 1991; 72: 859-866.

62. Aboagye-Mathiesen G, Toth FD, Juhl C et al. Characterization of Sendai virus-induced human placental trophoblast interferons. J Gen Virol 1991; 72: 1871-1876.

63. Cops SC, Giddings LE. Transplacental transmission of western equine encephalitis. Report of a case. Pediatrics 1959; 24 : 31-33.

64. Shinefield HR, Townsend TE. Transplacental transmission of western equine encephalitis. $J$ Pediatr $1953 ; 43: 21-25$.

65. Sweet RL, Gibbs RS. Infectious diseases of the female genital tract II. Baltimore, Williams and Wilkins. 1985: 204.

66. Doherty RL. Viral encephalitis in infectious diseases. In: Hoeprich PD (ed) Infectious diseases. Hagerstown, MD, Harper and Row. 1977: 919-927.

67. Spertzel RO, Crabbs CL, Vaughn RE. Transplacental transmission of Venezuelan equine encephalitis virus in mice. Infect Immun 1972; 6: 339-343.

68. Wenger F. Venezuelan equine encephalitis. Teratology 1977; 16: $359-362$. 